\title{
Evaluation of tissue repair using phytotherapeutic gel from Plectranthus neochilus, Schlechter (boldo-gambá) and Cnidoscolus quercifolius Pohl (favela) in Wistar rats
}

[Avaliação da reparação tecidual do gel fitoterápico de Plectranthus neochilus, Schlechter (Boldo-gambá) e Cnidoscolus quercifolius Pohl (Favela) em ratos Wistar]

\author{
M.S.A. Rêgo ${ }^{1}$, E.S. Franco ${ }^{2}$, R.A.S. Oliveira ${ }^{3 *}$, L.A.V. Linden $^{3}$, V.C.L. Silva ${ }^{4}$, \\ C.S. Maia ${ }^{6}$, M.N. Teixeira ${ }^{5}$, M.L.M. Marinho ${ }^{7}$, E.R. Lima $^{5}$ \\ ${ }^{1}$ Hospital Veterinário do Recife - Recife, PE \\ ${ }^{2}$ Centro Universitário Brasileiro - Recife, PE \\ ${ }^{3}$ Aluna de pós-graduação - Universidade Federal Rural de Pernambuco - Recife, PE \\ ${ }^{4}$ Médica veterinária autônoma - Recife, $\mathrm{PE}$ \\ ${ }^{5}$ Universidade Federal Rural de Pernambuco- Recife, PE \\ ${ }^{6}$ Universidade Federal de Pernambuco - Recife, PE \\ ${ }^{7}$ Universidade Federal de Campina Grande - Patos, PB
}

\begin{abstract}
The objective of this study was to investigate the effects of a gel formulation from the association of Plectranthus neochilus and Cnidoscolus quercifolius on tissue repair in cutaneous wounds in rats. A surgical wound was induced in 35 Wistar rats and treated according to group: G1 - commercial phytotherapeutic gel; G2 - Carbopol gel 1\%; G3, 4, 5 - gel formulation from Boldo-gambá and Favela (FGBF) at 2.5\%, 5\%, and 10\%, respectively. $1 \mathrm{ml}$ of the product was applied topically daily, for 14 days. Macroscopic evaluation of the wound showed inflammation, granulation, and epithelization in all groups. The FGBF $2.5 \%$ group showed greater angiogenic potential. There was a significant difference between the surgical area of the wounds treated with FGBF $2.5 \%$, $5 \%$, or $10 \%$ compared to the group with the commercial phytotherapeutic gel. On histomorphometry of the skin, there were reepithelization of the epidermis and superficial dermis, longitudinal collagen fibers, fibroblasts, and blood vessels, and in the deeper dermis, fibroblasts, transverse and longitudinal collagen fibers, blood vessels, and inflammatory cells. The $2.5 \%$ formulation had the greatest increase in fibroblast proliferation and most intense collagenization on day 14 of treatment.
\end{abstract}

Keywords: phytotherapy, dermatology, healing

\section{RESUMO}

Este trabalho objetivou investigar os efeitos de uma formulação em gel da associação da Plectranthus neochilus e da Cnidoscolus quercifolius no processo de reparação tecidual em feridas cutâneas de ratos. Foi induzida uma ferida cirúrgica em 35 ratos Wistar, sendo tratadas de acordo com os grupos: G1 - fitoterápico comercial; G2 - gel de carbopol 1\%; G3, G4 e G5 - formulação gel boldo-gambá mais favela (FGBF) 2,5\%, 5\% e 10\%, respectivamente. Aplicou-se $1 \mathrm{~mL}$ do produto, via tópica, diariamente, durante 14 dias. Na avaliação macroscópica das feridas, verificou-se inflamação, granulação e epitelização em todos os grupos. $O$ grupo FGBF 2,5\% apresentou maior potencial angiogênico. Houve diferença significativa entre as áreas cirúrgicas das feridas tratadas com os FGBF 2,5\%, 5\% ou 10\%, comparados ao grupo com o gel fitoterápico comercial. $\mathrm{Na}$ histomorfometria da pele, observou-se reepitelização da epiderme e da derme superficial, fibras colágenas longitudinais, fibroblastos e vasos sanguíneos e, na derme profunda, fibroblastos, fibras colágenas transversais e longitudinais, vasos sanguíneos e células inflamatórias. A formulação a 2,5\% teve o maior aumento na proliferação de fibroblastos e mais intensa colagenização no dia 14 de tratamento.

Palavras-chave: fitoterapia, dermatologia, cicatrização

Recebido em 4 de maio de 2020

Aceito em 27 de outubro de 2020

*Autor para correspondência (corresponding author)

E-mail: rhaysa.asoliveira@gmail.com 


\section{INTRODUCTION}

Medicinal plants and other natural products are widely used therapeutic resources that aid in cutaneous wound healing (Piriz et al., 2014). Plectranthus neochilus Schlechter, Boldo-gambá, has various uses in traditional medicine, including in the treatment of headaches, wounds, burns, dermatitis, allergy, insect and scorpion bites, and as an antiseptic agent (Ascensão et al., 1999). The Cnidoscolus quercifolius Pohl species, Faveleira or Favela, are used in ethnomedicine in general inflammations, such as ovarian inflammations, and also have an antioxidant activity (Peixoto Sobrinho et al., 2011).

An association of Plectranthus neochilus and Cnidoscolus quercifolius in a semisolid preparation has been used as a healing agent in skin lesions in animals, however, without the necessary scientific basis for its therapeutic efficacy to be established. Faced with the lack of research on this subject, the present objective was to investigate the effects of a gel formulation created from the association of Plectranthus neochilus and Cnidoscolus quercifolius in the tissue healing process in experimental wounds in rats.

\section{MATERIAL AND METHODS}

The areal parts of Plectranthus neochilus and bark of Cnidoscolus quercifolius were collected and a dried, a pressed sample of each plant was deposited in the Herbarium at the Federal Rural University of Pernambuco (UFRPE) under numbers 21717 and 21101, respectively. The hydroalcoholic extract was obtained at the Laboratory of Pharmacology of Bioactive Products of the Federal University of Pernambuco (UFPE). To obtain an organic extract, $500 \mathrm{~g}$ of the aerial parts of the Boldo-gambá and $500 \mathrm{~g}$ of the bark of the Favela were dehydrated in a circulating air oven at $60^{\circ} \mathrm{C}$, crushed, turned to dust, and weighed. To this material, $1 \mathrm{~L}$ of a solution (EtOH: WATER 1:1) was added, and it was left to rest for seven days at room temperature, after which it underwent vacuum filtration, that was repeated twice.

The liquids were taken to a rotary evaporator at a temperature of $40^{\circ}$ to $60^{\circ} \mathrm{C}$ and pressure of $650 \mathrm{mmHg}$. The aqueous part was frozen and lyophilized to produce the hydroalcoholic extracts, which were stored at $-20^{\circ} \mathrm{C}$, with a yield of $26.6 \%$ and $10 \%$ respectively. Carbopol at $1 \%$ was used as a vehicle and the $\mathrm{pH}$ of the gel was adjusted to 6.0 . For each $100 \mathrm{mg}$ of the vehicle, $2.5 \mathrm{mg}$ of the hydroalcoholic raw extract of Favela and $2.5 \mathrm{mg}$ of the hydroalcoholic raw extract of Boldo-gambá (FGBF 2.5\%) were used; in the $5.0 \%$ formulation, $5 \mathrm{mg}$ of each extract was used (FGBF 5\%), and in the $10 \%$ formulation, 10mg of each extract (FGBF 10\%).

Thirty-five male Wistar rats (Rattus norvegicus albinus), weighing between 220 and $250 \mathrm{~g}$, were obtained from the central vivarium at UFPE. They were kept in a temperature-controlled environment $\left(20-22^{\circ} \mathrm{C}\right)$, under artificial lighting, with a light/dark cycle $(12 / 12 \mathrm{~h})$, in individual metabolic cages, with free access to food and water. The first 15 days before surgery were considered an acclimation period. The experimental protocol was approved by the Ethics Committee for the Use of Animals (CEUA /UFPE), n. 23076.011939/2014-25. For the surgical procedure (after 12 hours of fasting), the rats were weighed and anesthetized with ketamine $(10 \mathrm{mg} / \mathrm{kg})$ and xylazine $(3 \mathrm{mg} / \mathrm{kg})$ (Andrade, 2002) given intraperitonially.

After induction of anesthesia, the animals were placed in ventral recumbency, fur was removed by epilation, and antisepsis done with iodine-alcohol at $0.1 \%$ on the dorsal midline of the cervical region of each animal. The incision area was marked with a marker pen and a metallic template $( \pm 78.5 \mathrm{~mm} 2)$. Removal of skin, subcutaneous tissue, fascia, and dermis were done using straight iris scissors and Adson tissue forceps. After incision, a silicone containment ring made from nontoxic and hypoallergenic material was sutured around the surgical wound using 4 to 6 simple interrupted sutures with 4.0 monofilament nylon, symmetrically distributed (Galiano et al., 2004; Franco et al., 2012), so that the wound remained centered. After surgery, the rats were randomly distributed into five groups $(n=7$ animals per group): Group 1, positive control treated with a commercially available phytotherapeutic gel (10ml of Calendula officinalis L. tincture; $10 \mathrm{ml}$ of Stryphnodendron barbatiman Mart. tincture; $5 \mathrm{ml}$ of Symphyntum officinalis L. tincture; $5 \mathrm{ml}$ of Aloe vera tincture; $3 \mathrm{ml}$ of Matricaria chamomilla $\mathrm{L}$. tincture; $5 \mathrm{ml}$ Echinacea angustifólia DC. tincture; $8 \mathrm{ml}$ propolis tincture, $100 \mathrm{~g}$ of Carbopol gel); Group 2, negative control, treated with the vehicle 
(Carbopol); Groups 3, 4, and 5, treated with the gel (Carbopol), which has a Plectranthus neochilus and Cnidoscolus quercifolius base at $2.5 \%, 5 \%$, and $10 \%$ concentrations, respectively.

All animals were treated during 14 consecutive days with $1 \mathrm{ml}$ of the specific gel for each group. Removal of crusts and residue was done on the seventh day to evaluate the healing process. The rats were weighed at the beginning of the treatment, and on the fourth, seventh, 10th, 13th, and 15th day after surgery. Contraction of the surgical wounds was measured daily using a digital caliper $\left(0-150 \mathrm{~mm}\right.$, Mitutoyo $\left.{ }^{\circledR}\right)$ according to the equation described by Bauer et al. (1966). The wounds were also evaluated for the presence of redness, edema, bleeding, secretion, odor, and crust.

The animals were fasted for 10 hours, then anesthetized with ketamine $(10 \mathrm{mg} / \mathrm{kg})$ and xylazine $(3 \mathrm{mg} / \mathrm{kg})$ and decapitated. Material was collected for histomorphometry of the cutaneous lesions (Tolosa et al., 2003). The slides were selected via sampling, examined under an optic microscope, and three images per field (area: $0.0018 \mathrm{~mm}^{2}$ ) were captured using a digital camera (magnifi-400x) connected to the microscope (Olympus BX-49 light microscope and camera). The images were stored, the blood vessels were counted, and the collagen density of all lesions was evaluated with the aid of digital markers, according to the method described by Rocha Júnior (2006).

Results were expressed in mean \pm standard error of the mean. For statistical analysis, a minimal significance of $0.05(\mathrm{p}<0.05)$ was considered. Normality of the measurements was evaluated using Kolmogorov Smirnov test. Parametric data were submitted to two-way Analysis of Variance (ANOVA), using the Bonferroni posttest. Data were analyzed statistically using Prism $^{\circledR} 4.00$ (GraphPad Software Inc., San Diego, California, US).

\section{RESULTS AND DISCUSSION}

Table 1 shows mean and standard error of the mean for the surgical area in the rats in the positive control, negative control, FGBF $2.5 \%$, FGBF 5\%, and FGBF $10 \%$ groups during the entire experiment. When mean areas were compared between groups, there were statistically significant differences $(\mathrm{P}<0.05)$. The wound areas decreased progressively in all groups. On the first day of treatment, in the groups FGBF 5\% and $10 \%$, a significant increase $(52.53 \%$ and $53.51 \%$ ) in mean and standard error of the mean was observed in the surgical area. From the second to the sixth day of treatment in the FGBF $2.5 \%$ group, there was a significant increase of $30.24 \%, 54.82 \%, 55.62 \%, 65.60 \%$ and $63.77 \%$. From the fourth to the sixth day of treatment, there was an increase in area of $71.07 \%, 59.65 \%$, and $94.49 \%$ in the group treated with FGBF $5 \%$ and of $54.32 \%, 94.91 \%$, and $116.70 \%$ in the FGBF $10 \%$ group.

On the eighth day of treatment in the $2.5 \%$ group, there was a significant increase of $115.30 \%$ compared with the group treated with the commercial phytotherapeutic gel. The groups treated with FGBF $2.5 \%, 5 \%$, and $10 \%$ had reepithelization in $87.72 \%, 87.72 \%$, and $57.15 \%$ of the rats on the $14^{\text {th }}$ day, respectively, while positive and negative control groups had $100 \%$. On the $14^{\text {th }}$ day after surgery, there was a significant statistical difference $(p=0.05)$, with mean area in the FGBF $10 \%$ group greater than the mean area of the other groups, demonstrating that there was a delay in the tissue repair process with this concentration. This was similar to the results from a study with hydroalcoholic extract from Aroeira (Schinus terebinthifolius Raddi) (Castelo Branco Neto et al., 2006).

Figure 1 (A, B, C, D, E, and F) shows excision wounds in rats from the positive and negative control groups in days zero, 7, and 14 of the experiment. Evolution of the wounds in groups FGBF $2.5 \%, 5 \%$, and $10 \%$ are shown in Figure 2 (A, B, C, D, E, F, G, H, and I).

The presence of exudate was observed in all groups in the first 48 hours after surgery. The presence of exudate in the first 48 to 72 hours is physiologic (Fernandes et al., 2007), as observed in all groups after surgery. The inflammatory process may delay healing (Pereira and Bartolo, 2016), which did not occur in this case. Tissue repair has hemostasis, inflammation, proliferation, and resolution phases (Sorg et al., 2017). 


\section{Rêgo et al.}

Table 1. Excisional surgical wound area in male Wistar rats (Rattus norvegicus albinus). in groups: positive control, negative control, and gel formulation from the association of Plectranthus neochilus and Cnidoscolus quercifolius in concentrations of $2.5 \%, 5 \%$, or $10 \%$

\begin{tabular}{lccccc}
\multicolumn{1}{c}{ Time } & $\begin{array}{c}\text { Commercial } \\
\text { phytotherapeutic agent }\end{array}$ & $\begin{array}{c}\text { Formulation } \\
\text { vehicle }\end{array}$ & $\begin{array}{c}\text { FGoups } \\
\text { FGB 2.5\% }\end{array}$ & FGBF 5\% & FGBF 10\% \\
\hline Zero (Start) & $301.99 \pm 11.63$ & $317.45 \pm 9.29$ & $336.55 \pm 7.71$ & $307.28 \pm 14.85$ & $333.28 \pm 10.61$ \\
$1^{\text {st }}$ & $187.47 \pm 18.44$ & $207.38 \pm 15.08$ & $234.58 \pm 12.94$ & $285.95 \pm 14.59^{*}$ & $287.71 \pm 26.29 *$ \\
$2^{\text {nd }}$ & $217.08 \pm 16.91$ & $208.33 \pm 7.52$ & $282.73 \pm 12.01^{*}$ & $273.94 \pm 20.25$ & $21.59 \pm 17.74$ \\
$3^{\text {rd }}$ & $188.75 \pm 18.09$ & $207.42 \pm 12.91$ & $292.24 \pm 12.02^{*}$ & $338.13 \pm 28.11^{*}$ & $272.31 \pm 19.41^{*}$ \\
$4^{\text {th }}$ & $172.63 \pm 17.31$ & $189.44 \pm 4.76$ & $268.65 \pm 10.73^{*}$ & $295.33 \pm 28.27^{*}$ & $266.41 \pm 13.38^{*}$ \\
$5^{\text {th }}$ & $141.55 \pm 12.29$ & $155.74 \pm 7.26$ & $234.41 \pm 8.06^{*}$ & $225.99 \pm 29.06^{*}$ & $275.90 \pm 20.26^{*}$ \\
$6^{\text {th }}$ & $130.70 \pm 14.37$ & $120.83 \pm 11.20$ & $214.05 \pm 20.43^{*}$ & $254.20 \pm 30.63^{*}$ & $283.23 \pm 30.44^{*}$ \\
$7^{\text {th }}$ & $107.81 \pm 15.09$ & $94.82 \pm 9.52$ & $152.27 \pm 11.54$ & $115.56 \pm 16.30$ & $95.23 \pm 12.31$ \\
$8^{\text {th }}$ & $62.40 \pm 8.09$ & $51.30 \pm 6.561$ & $134.35 \pm 7.13^{*}$ & $97.09 \pm 12.22$ & $101.93 \pm 11.06$ \\
$9^{\text {th }}$ & $52.55 \pm 14.12$ & $30.75 \pm 5.63$ & $74.44 \pm 12.62$ & $77.10 \pm 17.03$ & $75.97 \pm 20.42$ \\
$10^{\text {th }}$ & $36.49 \pm 9.97$ & $10.60 \pm 8.86$ & $47.03 \pm 14.54$ & $42.45 \pm 9.94$ & $46.16 \pm 19.81$ \\
$11^{\text {th }}$ & $8.11 \pm 4.42$ & $0.93 \pm 0.93$ & $22.94 \pm 7.32$ & $27.99 \pm 12.72$ & $52.27 \pm 19.08$ \\
$12^{\text {th }}$ & 0.00 & 0.00 & $26.71 \pm 11.91$ & $9.80 \pm 6.82$ & $20.06 \pm 6.47$ \\
$13^{\text {th }}$ & 0.00 & 0.00 & $15.54 \pm 10.62$ & $5.47 \pm 4.27$ & $6.56 \pm 3.26$ \\
$14^{\text {th }}$ & 0.00 & 0.00 & $4.44 \pm 4.44$ & $2.56 \pm 2.56$ & $7.87 \pm 5.07$ \\
\hline$V$ & & & &
\end{tabular}

Values shown in mean \pm standard error of the mean. Values tested using two-way ANOVA with a Bonferroni post hoc test. Significance* $(\mathrm{p}<0.05)$.



Figure 1. Evolution of the excisional wounds of male rats Wistar (Rattus norvegicus albinus) in the positive and negative control groups; A - Day zero; B - Day 7, before removal of the crust; C - Day 14 with full reepithelization (positive); D - Day zero; E - Day 7, before removal of the crust; F - Day 14 with full reepithelization (negative). 


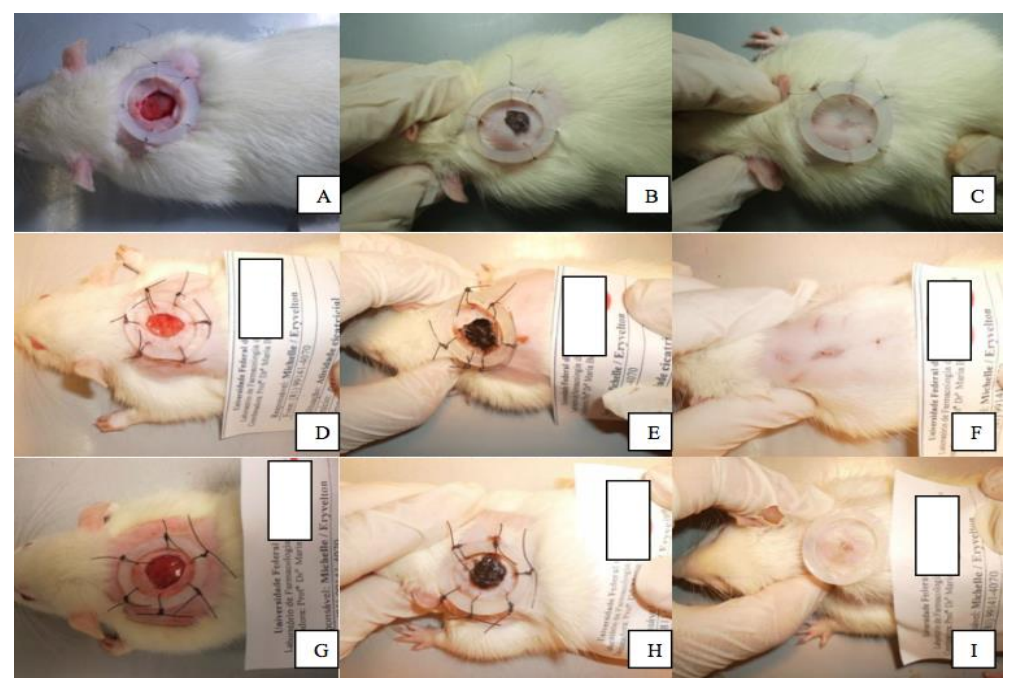

Figure 2. Evolution of the excisional wounds of male rats Wistar (Rattus norvegicus albinus) in groups FGBF 2.5\%, 5, and 10\%; A - Day zero; B - Day 7, before removal of the crust; C - Day 14 with total reepithelization (2.5\%), D - Day zero; E - Day 7, before removal of the crust; F - Day 14 with total reepithelization (5\%); $\mathrm{G}$ - Day zero; $\mathrm{H}$ - Day 7, before removal of the crust; I - Day 14 with total reepithelization $(10 \%)$.

The proliferative phase overlaps with the inflammatory phase and occurs from the $2^{\text {nd }}$ to the $10^{\text {th }}$ day after injury. It is characterized by migration and proliferation of different cell types and crust formation (Gonzalez et al., 2016). Formation of wound crusts occurred in all the treated animals, however, in those treated with FGBF $(2.5 \%, 5 \%$, or $10 \%)$ it was larger in size after the second day and had a brown color, which is compatible with the standard healing process. The mechanism for healing and tissue regeneration occurs after traumatic lesions or procedures (Greaves, et al., 2013). This suggests greater cell activity with a decrease of wound area, of formation of granulation tissue, and of epithelium (Serra et al., 2017).

Figure 3 shows the evolution in body weight of the male Wistar rats during the experiment. It was statistically significant for the FGBF $10 \%$ group between days zero, seven, ten, and thirteen. Animals with dermatologic lesions, accompanied by pruritus and pain, do not eat well and lose weight (Batista et al., 2012). In all groups, there was a weight increase during treatment. The authors suggest that the uniform care provided did not affect water or feed intake or significant clinical reactions such as intense pruritus, erythema, behavior changes, or deaths.

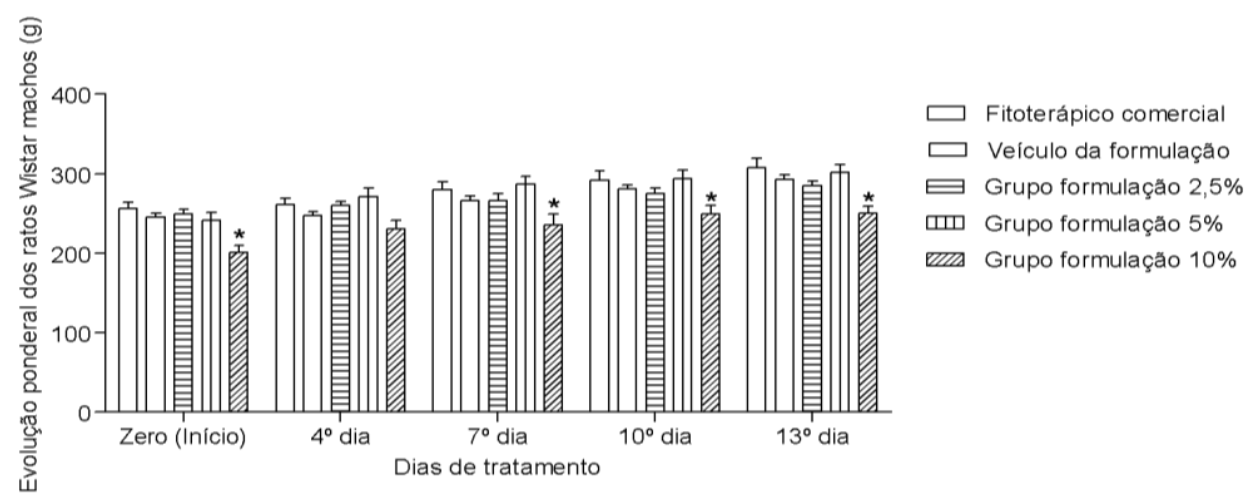

Figure 3. Evolution of body weight ( $\mathrm{g}$ ) of the male Wistar rats (Rattus norvegicus albinus) treated with a commercial phytotherapeutic agent, formulation vehicle, and FGBF formulations $(2.5 \%, 5 \%$, or $10 \%)$. 
The results presented in Figure 4 show that when comparing thickness of the epithelium, there were no statistical differences between groups. However, the FGBG $2.5 \%$ group had greater thickness, while the FGBG $10 \%$ group had a lower value. Also, the commercial phytotherapeutic agent and the FGBG 5\% groups had similar values when compared. Macrophages are phagocytic hematopoietic cells in the myeloid lineage and are one of the main cells involved in the transition between the inflammatory and proliferative phase. Studies have proven that their absence during these phases result in a decrease in tissue formation and hemorrhage (Landén et al., 2016). From the macroscopic evaluation of the thickness of the epithelium, it is suggested that the FGBG $2.5 \%$ group had the best reepithelization during the transition from the inflammatory phase to the proliferative phase when compared to the other concentrations. The results shown in Figure 5 showed that there was a statistically significant difference in groups FGBF 5\% and 10\%, which had a lower amount of collagen compared with the rest.
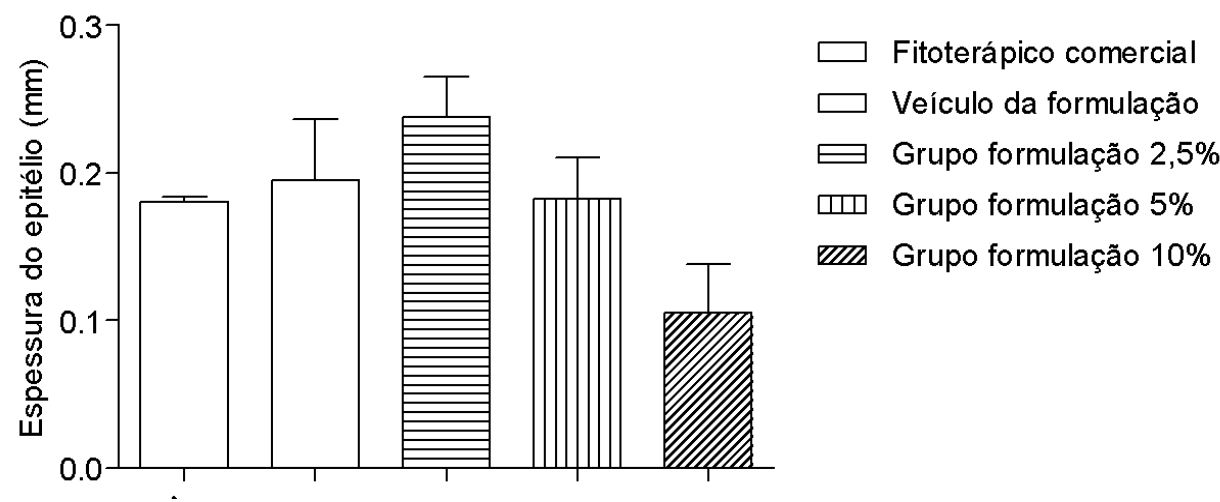

Figure 4. Thickness of the epithelium of male Wistar rats (Rattus norvegicus albinus) treated with commercial phytotherapeutic agent, formulation vehicle, and the formulations of FGBF $(2.5 \%, 5 \%$, or $10 \%)$.


Figure 5. Quantification of collagen in the skin of male Wistar rats (Rattus norvegicus albinus) treated with a commercial phytotherapeutic agent, formulation vehicle, and FGBF formulations $(2.5 \%, 5 \%$, or $10 \%)$

The gel formulation from the hydroalcoholic extracts of Plectranthus neochilus and Cnidoscolus quercifolius did not show dermal or hepatic toxicity. However, acute toxicity from the hydroalcoholic extract of these plants is relatively low, with a LD50 greater than $2 \mathrm{~g} / \mathrm{kg}$ when given via gavage (Rêgo et. al., 2018). The cytotoxic activity of the Plectranthus neochilus (Borges et al., 2016) and Cnidoscolus quercifolius (Ribeiro et al., 2020) species has been reported. Cnidoscolus quercifolius oil did not show cytotoxic potential in vitro against non-neoplastic cells and there were no deaths during the acute oral toxicity test (Ribeiro et al., 2020). Cnidoscolus quercifolius oil did not show cytotoxic potential in vitro against non-neoplastic 
cells and there were no deaths during the acute oral toxicity test (Borges et al., 2016).

It is possible to associate the results obtained by Borges et al. (2016) with the low reepithelization $(57.15 \%)$ in the FGBF $10 \%$ group (Table 1 and Figure 4) and lower amount of collagen in the FGBF 5\% and 10\% treatment groups (Figure 5). In Figure 6, there was no significant statistical difference in the studied groups. The FGBF $2.5 \%$ group showed a greater quantity of vessels when compared to other groups. The formulation vehicle group had the smallest result.

Regarding the histomorphometric study of the skin in the commercial phytotherapeutic agent group (positive control), complete reepithelization of the epidermis and superficial dermis with the presence of longitudinal collagen fibers, fibroblasts, and blood vessels (Figure 7A), and in the deep dermis of the skin, fibroblasts, transverse and longitudinal collagen fibers, blood vessels, and rare inflammatory cells (Figure 7B) were observed. In the formulation vehicle group (negative control), the skin showed complete reepithelization of the epidermis and superficial dermis with the presence of longitudinal collagen fibers, fibroblasts, fibrocytes, and blood vessels (Figure 8A), and on examination of the deep dermis, there were fibroblasts, longitudinal and transverse collagen fibers, blood vessels, and few mononuclear inflammatory cells (Figure 8B).

In the FGBF $2.5 \%$ group, histomorphometry showed complete reepithelization of the epidermis and superficial dermis of the skin with the presence of longitudinal and transverse collagen fibers and several blood vessels (Figure 9A) and the deep dermis of the skin, showing several fibroblasts, collagen fibers, blood vessels, and few mononuclear inflammatory cells (Figure 9B).
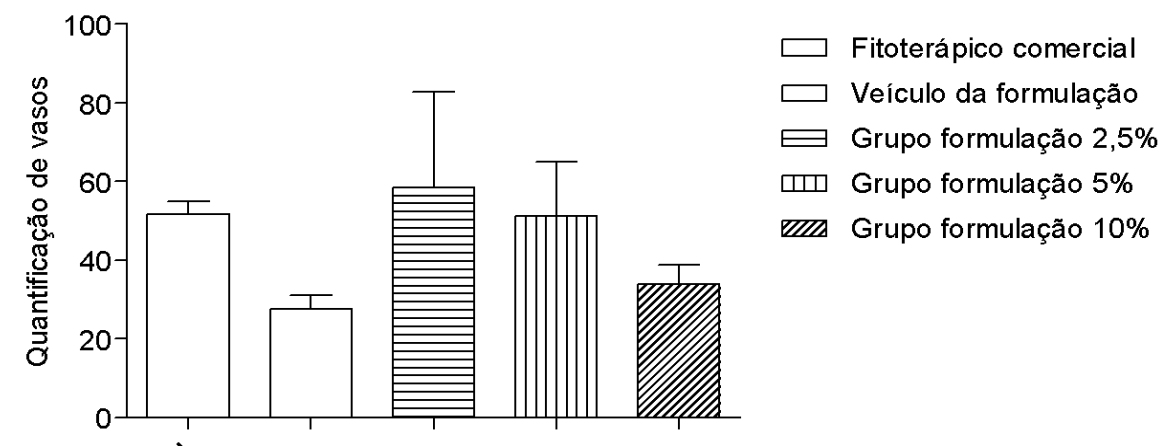

Figure 6. Quantification of blood vessels in the skin of male Wistar rats (Rattus norvegicus albinus) treated with commercial phytotherapeutic agent, formulation vehicle, and FGBF formulations $(2.5 \%, 5 \%$, or $10 \%)$

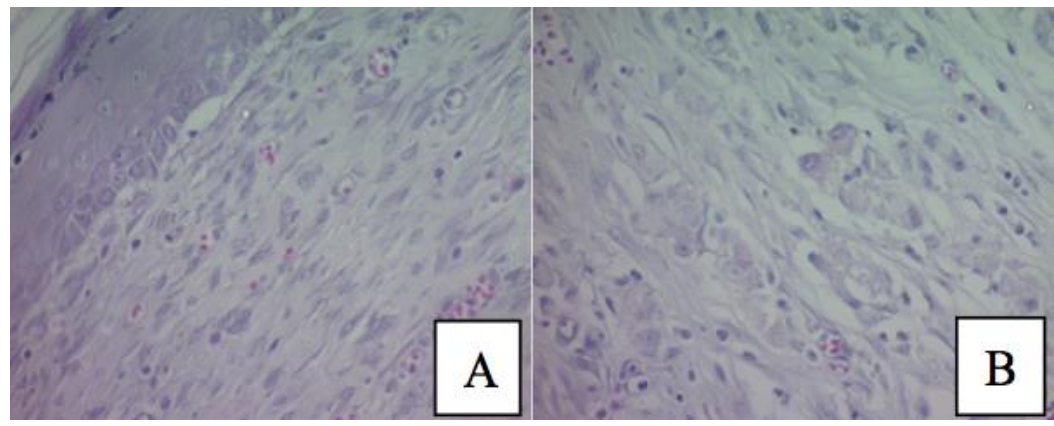

Figure 7. A- Photomicrograph of the skin of male Wistar rats (Rattus norvegicus albinus) from the positive control group showing complete reepithelization of the epidermis and superficial dermis with the presence of longitudinal collagen fibers, fibroblasts, and blood vessels. B - Photomicrograph of the deep dermis of the skin of rats in the positive control group, showing fibroblasts, transverse and longitudinal blood vessels, and rare inflammatory cells. AU 400X; H.E. stain. 


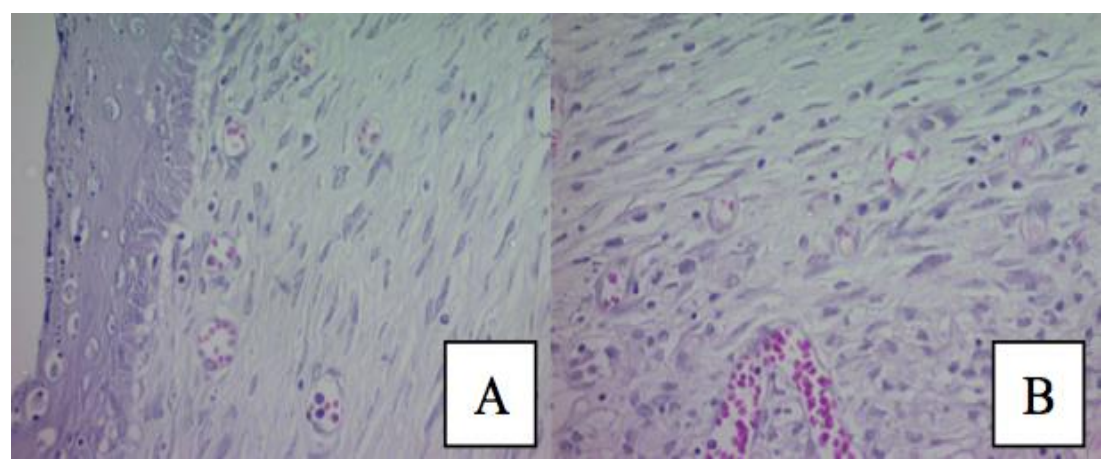

Figure 8. A- Photomicrograph of the skin of male Wistar rats (Rattus norvegicus albinus) from the negative control group, showing complete reepithelization of the epidermis and superficial dermis with the presence of longitudinal collagen fibers, fibroblasts, fibrocytes, and blood vessels. B - Photomicrograph of the deep dermis of the skin showing fibroblasts, longitudinal and transverse collagen fibers, blood vessels and few mononuclear inflammatory cells. AU 400X; H.E. stain.

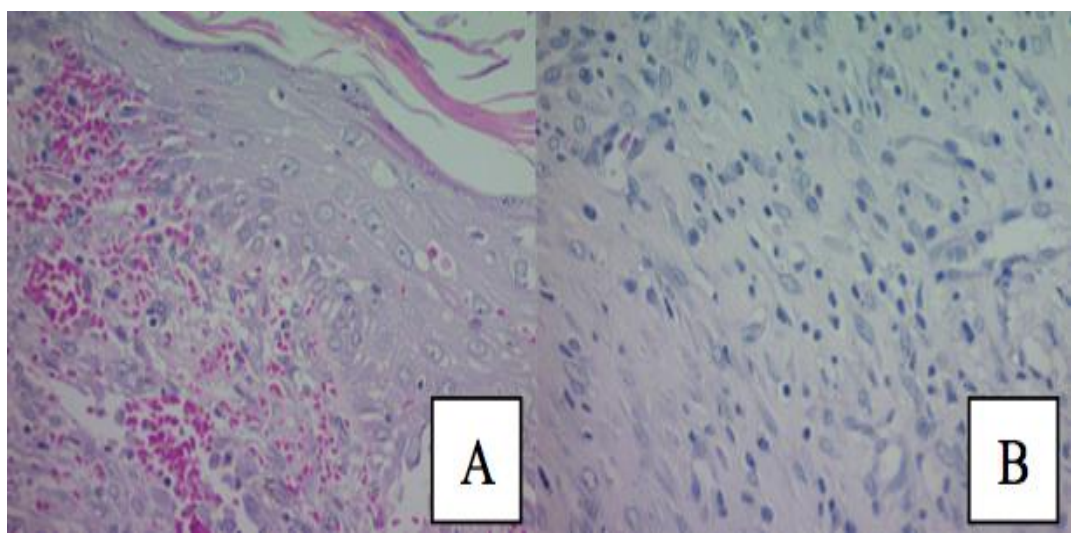

Figure 9. A - Photomicrograph of the skin of male Wistar rats (Rattus norvegicus albinus) in the FGBF $2.5 \%$ group, showing complete reepithelization of the epidermis and superficial dermis with the presence of longitudinal and transverse collagen fibers, fibroblasts and several blood vessels. B - Photomicrograph of the deep dermis of the skin, showing several fibroblasts, collagen fibers, blood vessels, and few mononuclear inflammatory cells. AU 400X; H.E. stain.

In the proliferative phase, there is reepithelization, fibroplasia, and angiogenesis, respectively. It is essential for the supply of oxygen and nutrients needed for healing (Childs and Murthy, 2017). The FGBF $2.5 \%$ group had the largest amount of macroscopic vessels compared with the others, that is, it had the greatest angiogenic potential (Figure 6 and 9B). The new capillaries in an open wound merge and grow in the same direction, which contributes toward the synthesis of extracellular matrix (ECM) and formation of granulation tissue (Mendonça; Coutinho-Netto, 2009). Crucial components of wound repair are ECM and stromal stem cells (fibroblasts, myofibroblasts) (Ackermann, 2013). On histomorphometry of the FGBF $5 \%$ group, the skin showed full reepithelization of the epidermis, however, stratum corneum is not shown in this image. It was possible to observe superficial dermis with longitudinal collagen fibers, fibroblasts, and several blood vessels (Figure 10A) and in the deep dermis of the skin, several diffuse mononuclear inflammatory cells amidst collagen fibers, fibroblasts, and blood vessels (Figure 10B).

In the FGBF $10 \%$ group, the skin showed complete reepithelization of the epidermis and dermis with the presence of fibroblasts and blood vessels (Figure 11A) and on deep analysis of the skin, showing several diffuse mononuclear inflammatory cells amidst collagen fibers, fibroblasts, and blood vessels (Figure 11B). 




Figure 10. A- Photomicrograph of the skin of male Wistar rats (Rattus norvegicus albinus) in the FGBF $5 \%$ group, showing complete reepithelization of the epidermis, however, the stratum corneum is not seen in this image. Superficial dermis with longitudinal collagen fibers, fibroblasts, and several blood vessels. B - Photomicrograph of the deep dermis of the skin showing several diffuse mononuclear inflammatory cells amidst collagen fibers, fibroblasts, and blood vessels. AU 400X; H.E. stain.



Figure 11. A - Photomicrograph of the skin of male Wistar rats (Rattus norvegicus albinus) of the FGBF $10 \%$ group, showing complete reepithelization of the epidermis and dermis of the presence of fibroblasts and blood vessels. B - Photomicrograph of the deep dermis of the skin, showing a great number of diffuse mononuclear inflammatory cells amidst collagen fibers, fibroblasts, and blood vessels. AU 400X; H.E. stain.

On histomorphometric analysis to evaluate treatment with $\operatorname{FGBF}(2.5 \%, 5 \%$, and $10 \%)$, healing by second intention was evaluated by presence of dermal papillae, number of blood vessels, number of fibroblasts and density of the collagen, the histological morphology of the dermis was evaluated after 14 days of treatment and compared with the control groups. It was observed that $100 \%$ of the animals (sampling) in the groups treated with FGBF $(2.5 \%, 5 \%$, and $10 \%$ ) and positive and negative control groups showed complete reepithelization, as well as skin resistance. Photomicrography of the groups treated with FGBF 5\% (Figure 10B) and 10\% (Figure 11B) showed several mononuclear inflammatory cells. Linoleic acid is the main fatty acid in the seed oil from Cnidoscolus quercifolius and has long been considered a pro-inflammatory agent (Ribeiro et al., 2020).
However, the anti-inflammatory activity of Favela seed oil was confirmed via a carrageenaninduced peritonitis essay, which significantly reduced the pro-inflammatory mediator TNF- $\alpha$ in the plasma of mice (Ribeiro et al., 2020). In the group treated with FGBF $2.5 \%$ (Figures 6 and 9B), mononuclear inflammatory cells were not observed. As for the antimicrobial essays from the hydroalcoholic extracts of Plectranthus neochilus or Cnidoscolus quercifolius and the association of the two plants using strains of Staphylococcus aureus, Staphylococcus epidermides, and Escherichia coli, results showed that they were not sensitive to the isolated extracts or the association. This contradicts reports that plants of the genus Plectranthus spp. and Cnidoscolus spp. have antimicrobial activity (Santos et al, 2014; Adeniran et al, 2012). 


\section{CONCLUSIONS}

The use of a phytotherapeutic gel from the association of Plectranthus neochilus (Boldogambá) and Cnidoscolus quercifolius (Favela) at concentrations of $2.5 \%, 5 \%$ or $10 \%$ did not result in any decrease in the duration of the healing process in cutaneous wounds in Wistar rats. The $2.5 \%$ formulation had the greatest increase in fibroblast proliferation and the most intense collagenization on day 14 of treatment.

\section{ACKNOWLEDGEMENTS}

We are grateful to CAPES.

\section{REFERENCES}

ACKERMANN, M.R. Cicatrização de feridas e angiogênese. In: ZACHARY, J.F.; MCGAVIN, M.D. Bases da patologia em veterinária. Rio de Janeiro: Elsevier Brasil, 2013. p.357-359.

ADENIRAN, O.I.; OLAJIDE, O.O.; IGWEMMAR, N.C.; ORISHADIPE, A.T. Phytochemical constituents, antimicrobial and antioxidant potentials of tree spinach [Cnidoscolus aconitifolius (Miller) I. M. Johnston]. Acad. J., v.7, p.1317-1322, 2013.

ANDRADE, S.F. Manual de terapêutica veterinário. São Paulo: Rocca, 2002. p.250-255.

ASCENSÃO, L.; MOTA, L.; CASTRO, M. Glandular trichomes on the leaves and flowers of Plectranthus ornatus: morphology, distribution and histochemistry. Ann.Botany, v.84, p.437-447, 1999.

BATISTA, L.L.; CAMPESATTO, E.A.; ASSIS, M.L. et al. Estudo comparativo do uso tópico de própolis verde e vermelha na reparação de feridas em ratos. Rev. Colégio Bras. Cir., v.39, p.515$520,2012$.

BAUER, A.W.; KIRBY, W.M.M.; SHERRIS J.C.; TURCK, M. Antibiotic susceptibility testing by a standardized single disk method. Am. J. Clin. Pathol., v.45, p.149-158, 1966.

BORGES, G.A.; FERREIRA, J.F.; ELIAS, S.T. et al. Avaliação do extrato hidroalcoólico de Aroeira (Schinus terebinthifolius Raddi) no processo de cicatrização de feridas em pele de ratos. Acta Cir. Bras., v.21, p.17-22, 2016.
CASTELO BRANCO NETO, M.L.; RIBAS FILHO, J.M.; MALAFAIA, O. et al. Avaliação do extrato hidroalcoólico de Aroeira (Schinus terebinthifolius Raddi) no processo de cicatrização de feridas em pele de ratos. Acta Cir. Bras., v.21, Supl.2, p.17-22, 2006.

CHILDS, D.R.; MURTHY, A.S. Overview of wound healing and management. Surg. Clin. N. Am., v.97, p.189-207. 2017.

FERNANDES, E.S.; PASSOS, G.F.; MEDEIROS, R. et al. Antiinflammatory effects of compounds alpha-humulene and transcaryophyllene isolated from the essential oil of Cordia verbenacea. Eur. J. Pharmacol., v.569, p.228-236, 2007.

FRANCO, E.S.; AQUINO, C.M.F.; MEDEIROS, P.L. et. al. Effect of a semisolid formulation of Linum usitatissimum L. (Linseed) oil on the repair of skin wounds. Evid. Based Complement. Alternat. Med., v.2012, p.270752, 2012.

GALIANO, R.D.; MICHAELS, L.V.; DOBRYANSKY, M. et al. Quantitative and reproducible murine model of incisional wound healing. Wound Repair Regen., v.12, p.485-492, 2004.

GONZALEZ, A.C.O.; COSTA, T.F.; ANDRADE, Z.A.; MEDRADO, A.R.A.P. Wound healing - a literature review. Anais Bras. Dermatol., v.91, p.614-620, 2016.

GREAVES, N.S.; IQBAL, S.A.; BAGUNEID, M.; BAYAT, A. The role of skin substitutes in the management of chronic cutaneous wounds. Wound Repair Regen., v.21, p.194-210, 2013.

LANDÉN, N.X.; LI, D.; STÅHLE, M. Transition from inflammation to proliferation: a critical step during wound healing. Cell. Mol. Life Sci., v.73, p.3861-3885, 2016.

MENDONÇA, R.J.; COUTINHO-NETTO, J. Aspectos celulares da cicatrização. An. Bras. Dermatol., v.84, p.257-62, 2009.

PEIXOTO SOBRINHO, T.J.S.; CASTRO, V.T.N.A.; SARAIVA, A.M. et al. Phenolic content and antioxidant capacity of four Cnidoscolus species (Euphorbiaceae) used as ethnopharmacologicals in Caatinga, Brazil. Afr. $J$. Pharm. Pharmacol., v.5, p.2310-2316, 2011.

PEREIRA, R.F.; BARTOLO, P.J. Traditional therapies for skin wound healing. Adv. Wound Care, v.5, p.208-229, 2016. 
PIRIZ, M.A.; LIMA, C.A.B.; JARDIM, ZV.M.R. et al. Plantas medicinais no processo de cicatrização de feridas: uma revisão de literatura. Rev. Bras. Plantas Med., v.16, p.628-636, 2014.

RÊGO, M.S.A.; SILVA, V.C.L.; MAIA, C.S. et al. Avaliação da segurança do extrato hidroalcoólico de partes aéreas de Plectranthus neochilus Schlechter, Lamiaceae e entrecascas de Cnidoscolus quercifolius Pohl, Eupharbiaceae em roedores. Med. Vet. v.12, p.82-92, 2018.

RIBEIRO, P.P.C.; DAMASCENO, K.S.F.C.S.C.; VERAS, B.O. et al. Chemical and biological activities of faveleira (Cnidoscolus quercifolius Pohl) seed oil for potential health applications. Food Chem., v.337, p.127771, 2020.

ROCHA JÚNIOR, A.M.; OLIVEIRA, R.G.; FARIAS, L.C.R. et al. Modulação da proliferação fibroblástica e da resposta inflamatória pela terapia a laser de baixa intensidade no processo de reparo tecidual. An. Bras. Dermatol., v.81, p.150156, 2006.
SANTOS, L.A.; MENEZES, J.S.; RUFINO, L.R.A. et al. Determinação da atividade antimicrobiana do extrato Hidroalcoólico da planta Plectranthus ornatus Codd (Boldo Chinês). Rev. Univ. Vale do Rio Verde, v.12, p.119-129, 2014.

SERRA, M.B.; BARROSO, W.A.; SILVA, N.N. et al. From inflammation to current and alternative therapies involved in wound healing. Int. J. Inflam., v.2017, p.1-17, 2017.

SORG, H.; TILKORN, D.J.; HAGER, S. et al. Skin wound healing: an update on the current knowledge and concepts. Eur. Surg. Res., v.58, p.81-94, 2017.

TOLOSA, E.M.C.; RODRIGUES, C.J.; BEHMER, O.A.; FREITAS-NETO, A.G. Manual de técnicas para histologia normal e patológica. 2.ed. São Paulo: Manole, 2003. 331p. 